\title{
Glioma に対する長期免疫・化学療法の治療成績
}

\author{
久間 祥多・中島電・篗永 正道 \\ 山下 拨紀・桑原 武夫
}

\section{Maintenance Immunochemotherapy for Gliomas}

\author{
Yoshikazu Kyuma, Fumoto Nakajima, Masamichi Shinonaga, \\ Toshinori Yamashita and Takeo Kuwabara
}

Department of Neurosurgery, Yokohama City University, Yokohama 232

\begin{abstract}
Summary
Adjuvant immunochemotherapy and irradiation therapy were applied following surgery for gliomas from 1975 to 1978.It is the authors' principle to remove the tumor extensively. About one week after the operation,irradiation was started. Along with the irradiation, adjuvant immunochemotherapy was also started. For supratentorial gliomas, initially, adriamycin was given in three divided dosis of $0.5 \mathrm{mg} / \mathrm{kg}$, up to $30 \mathrm{mg}$, on every other day. After a rest of 6 weeks,methyl-CCNU was given in a single dose of $3 \mathrm{mg} / \mathrm{kg}$ orally. This course of treatment was repeated after another 6 weeks. Along with the chemotherapy, OK-432 was given as an immunopotentiator. For medulloblastomas, methyl-CCNU was given at first, in a single dose of $3 \mathrm{mg} / \mathrm{kg}$. After a rest of 6 weeks, methotrexate was given intrathecally via an Ommaya reservoir on five successive days in a single dose of $0.25 \mathrm{mg} / \mathrm{kg}$. After another 6 weeks methyl-CCNU was repeated every 6 weeks. Methotrexate was also given during the spring, summer and winter vacations. OK-432 was also administered. This combined therapy was applied to 14 cases of supratentorial malignant gliomas, seven cases of supratentorial low grade gliomas, and 10 cases of medulloblastomas. In addition, nine low grade gliomas in the brain stem without surgery received this therapy.

The survival rate of supratentorial malignant gliomas was $79 \%$ for one year, $50 \%$ for two years and $46 \%$ for three years. The survival rate of medulloblastomas was $80 \%$ for one year, $67 \%$ for two years, and $57 \%$ for three years. All the survivors among medulloblastoma cases could go to school or kindergarden.

Toxicity was examined by white blood cell count, liver function, renal function and lymphocyte count. The difference of mean white blood cell counts between the first postoperative year and thereafter was not significant. GOT and GPT were elevated in the early postoperative period, but returned to normal values in the late postoperative period. ALP increased in the late postoperative period. Throughout the course of immunotherapy, it is necessary to measure immunoparameters. Lymphocyte count and PPD skin test were measured. Difference of lymphocyte counts between the first postoperative year and thereafter was not significant. Although the lymphocyte count was said to be depressed in glioma cases, and especially during chemotherapy, this series showed no apparent immunosuppression. Because some toxicity, such as elevating ALP, was noted, it seems better to discontinue the combined therapy at the end of the second postoperative year.
\end{abstract}

\section{Key words: glioma, combined immunochemotherapy, Me-CCNU, methotrexate, streptococcus pyogenes preparation $(\mathrm{OK}-432)$}

\footnotetext{
横浜市立大学媨神経外科

〔連絡先： 于 232 横泜市南区浦舟町4-56, 横浜市立大学脳神経外科, 久間祥多〕

1981年 4 月13日 受稿
} 


\section{Iはじめに}

脱腫瘍に対する化学療法は，nitrosourea 系の制癌郕の 導入以来，本剂を中心として活発に行われるようにな り，欧米に括计る randomized studyに括いてむ，手術お よび放射線治療に加えて化学療法を施行することによ り，コントロール群に比して好成績を収めうることが報 告されている17)，さらに成績を向上させるために，計画 的に長期にわたり，かつ多剤併用による治療が一般的に なりつつある，我が国において，脳腫瘍に対する化学癔 法の現状は,全国脳腫瘍集計調查 ${ }^{8)}$ 亿よれば， $3 \%$ の施設 で実施されているにすぎない，我々は gliomaに対して 1- (2-chloroethyl) -3- (4-methyl-cyclohexyl) - I-nitrosourea $(\mathrm{Me}-\mathrm{CCNU})$ を軸とする多郕療法に，さらに免疫療 法凨上して OK-432を加えた免疫・化学療法を実施して おり，開始上り 5 年が経過し，症例が增加したので，治 療成績ならびに長期投与による全身的な影響について検 討した。

\section{II 対象および方法}

症例怯, 天幕上 malignant glioma 14 例, low grade glioma 7 例，および medulloblastoma 10例の手術例のほ かに，橋㧍よび脑幹の low grade glioma と診断された非 手術例 9 例の計40例である，手術例においては，神経学 的な欠損症状を生じない範囲で可及的底沉囲にわたり腫 瘍を剔出するのを原則としている，通常は吸引管により 腫湟と正常脳組織の間を吸引しつつ切離 し, 寸なわち sucker dissection techniqueにより腫瘍を一塊として剔出 する，手術後，天幕上の gliomaに対しては（Fig. 1)， $6,000 \mathrm{R} の$ Lineac 照射と平行して，まずadriamycin 0.4 $\sim 0.6 \mathrm{mg} / \mathrm{kg}$ 隔日に 3 回投与し， 6 週後にMe-CCNU を $3 \mathrm{mg} / \mathrm{kg}$ 投与する．以後はこの繰り返しで治療を続け る、しかし，adriamycin偪作用が強いので術後 1 年以 内に投与を止めて，以後は $\mathrm{Me}-\mathrm{CCNU}$ を6 週間ごとに 続ける。OK-432 は術後すくより $0.5 \mathrm{KE}$ で開始し，漸 增して $2 \mathrm{KE}$ を維持量として，入院中は週 3 回，退院後 は週 1 回を続ける. Medulloblastoma には (Fig. 2)，術 後 Lineac 在全腷に $5,000 \mathrm{R}$ ，泰椎に $3,500 \mathrm{R}$ 照射す る。これと平行して，まず $\mathrm{Me}-\mathrm{CCNU}$ を $3 \mathrm{mg} / \mathrm{kg}$ 投与 し，6週後に Ommaya reservoirより methotrexateを

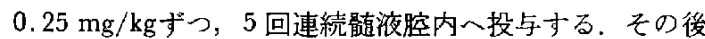
は Me-CCNU を6 週間ごとに投与しつつける. Methotrexateは，春夏冬の休双に入院させて前と同じ方法によ って投与する. OK-432は0.05 KE 上り漸増して，入院 中法週 3 回，退院後は $0.5 \mathrm{KE}$ 老䧽持量として週 1 回続 admission outpatient clinic

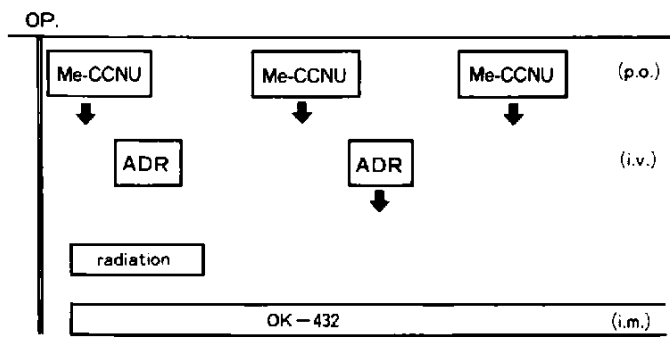

Fig. 1 The authors' policy of immunochemotherapy for malignant gliomas. Me-CCNU: methylCCNU, ADR: adriamycin.

admission outpatient clinic

OP.

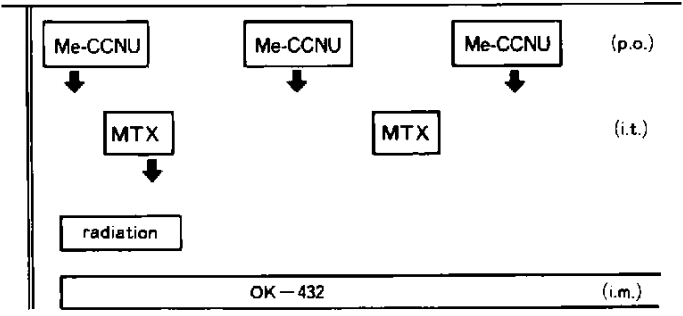

Fig. 2 The author's policy of immunochemotherapy for medulloblastomas. MTX: methotrexate.

ける. 非手術的に脳幹部の glioma と診断された群は， 天幕上 glioma に対する術後療法と同じ方法で治療され る。治療継続の期限仙設定してなく, 最長では 3 年間, Me-CCNU の総量は2,760 mg に達した。

\section{I 結 果}

\section{1. 治療成转}

治療成績は術捘の生存期間によって判定した. Benign cases 注 follow up 期間が不十分であるため， malignant cases のみの生存期間について述べる，天幕上 $の$ malignant glioma では (Fig. 3)，1 年生存率が79\%，2 年生存 率が $50 \% ， 3$ 年生存率が $46 \%$ であった．生存期間ととも に生存の質も重要であり，生存率のグラフに Karnofsky scale も記入した．手術後1 年ごとに 全国譄腫瘍集計委 員会の scale に従い，各生存者の scale の分布を百分率 で示した．術後 3 年目といえども手術時に比して大差の ないことがわかる．Medulloblastoma では，1年生存率 が $80 \% ， 2$ 年生存率が $67 \% ， 3$ 年生存率は $57 \%$ であっ た，生存者は全例，学校または幼稚園人通っている。

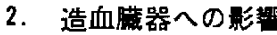

Me-CCNU投与後， 1 週閒ごとに 6 週閒目まで白血球 数および血小板数を算定し，それらの平均值括よび標準 


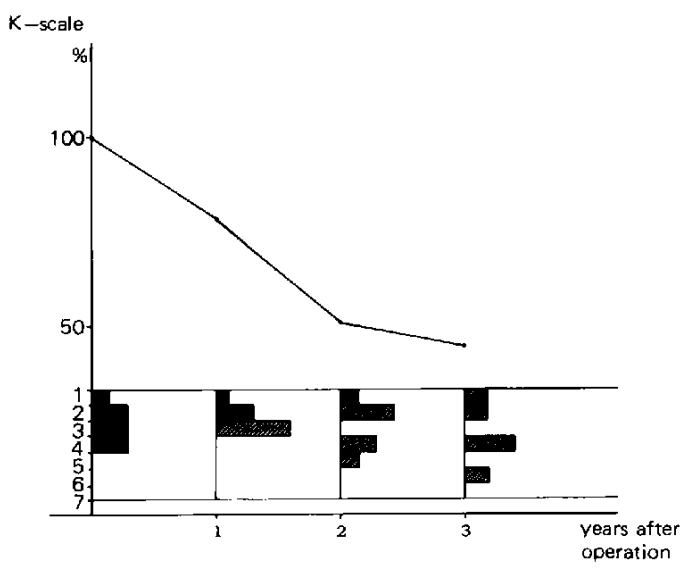

Fig. 3 Survival rate of malignant glioma cases above and distribution of Karnofsky scale of living patients below.

偏差を求めるとFig. 4 のごとくであった。すなち， 白血球数は 3 週間後にもっ上も低值を示し，4,758士904 まで低下し，その後は元の值一戻った。これを成人例と 小児例に分けてみると，成人例では同様に 3 週間後にも っとも低值を示すが，4,833士847とその影響は少なく，

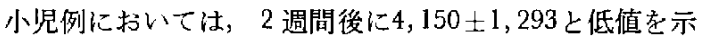
すものが多かった. 血小板数は，4週間後にもっとも低 下し $(22.3 \pm 6.7) \times 10^{4}$ となっているが，すぐに元の值へ 戻った。ついで長期にわたる併用療法の影響をみるため に，白血球数について， 1 年以内と 1 年後以降に分けて 影響を比較すると，Fig. 5 のごとく明らかな差は示して いなか力た．しかし個々の例では，術後 2 年を過ぎてか ら骨髄抑制が目立ってくるものが散見され，2 年過ぎま で何の抑制もみられなかったにもかか力らず，術後 2 年 $2 \sim 3$ 力月で赤血球が300万以下, 白血球が3,000以下に 低迷したものが 3 例みられた。

\section{3. 肝機能への影部}

肝機能として GOT, GPT, アルカリフォスフォター ゼについて検査を行った，GOT では術前および術直後 でややばらつきがあるものの，1年以上経過した遠隔時 には，ほとんどの例が正常範囲に落ら着いた，GPTは術 前および術直後では GOTに比してばらつきがやや大き いが,遠隔時にはほとんどが正常範囲内に戻った。一方， アルカリフォスファターゼは(Fig. 6)，手術直後から遠 隔時にかけて上昇している例が 6 例あり，そのうちの3 例が異常值を示し，3 例は正常上限にあった。一番の高 值を示した例でMe-CCNUを中断して経過をみていた が，3力月後でも変化がないので投与を再開している.

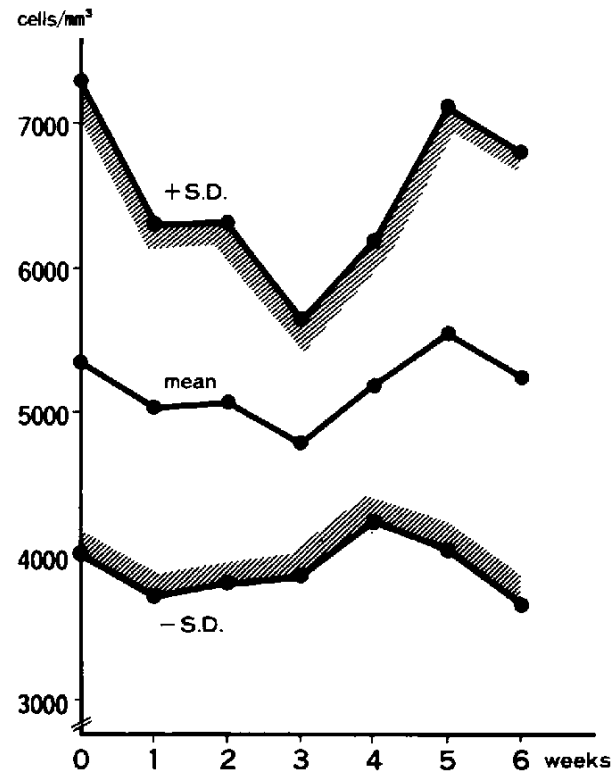

Fig. 4 Weekly measurement of WBC count after administration of $\mathrm{Me}-\mathrm{CCNU}$ and $\mathrm{OK}-432$.

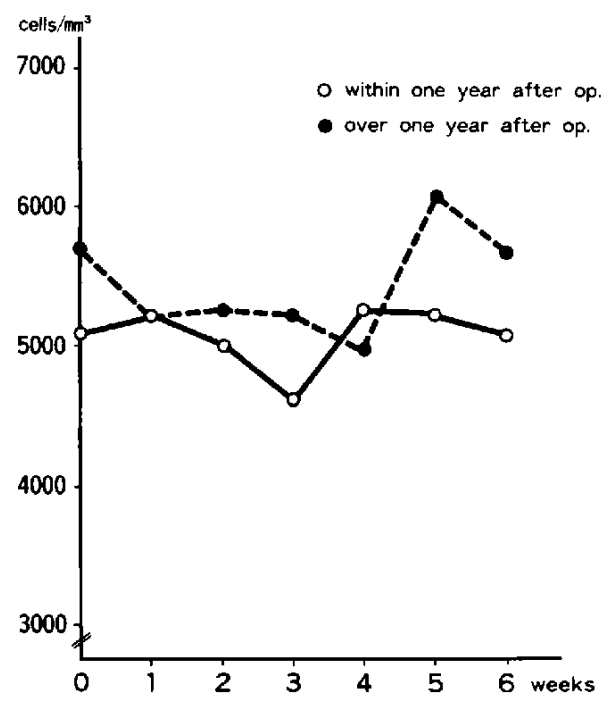

Fig. 5 Late effect of immunochemotherapy to WBC count. Comparison between the first postoperative year and thereafter.

\section{4. 督譏能への影䅉}

腎機能はBUNをを参考にして長期の経過をみている が，変動幅は小さく，すべて $18 \mathrm{mg} / \mathrm{d} l$ 以下にあり，腎 不全の徴候を示した例はなかった。 


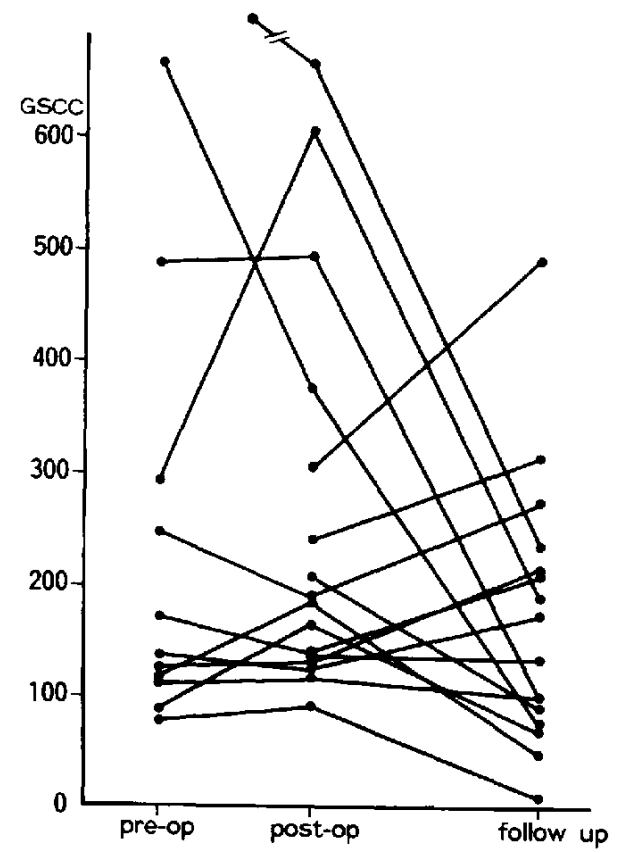

Fig. 6 Late effect of immunochemotherapy on alkalincphosphatase.

\section{5. 免疫能への影霎}

兔疫学的バラメーターの推移を追跡していくことは， 免疫療法を行っていく上に重要なことである。初めより 一貫して検查しているパラメーターは，末梢りンパ球数 および PPD 皮内反応である。 Me-CCNU 投与による影 響をみるために，リンパ球数の平均值を 1 週間ごとに算 定する上，変動㤝きわめて小幅であった．1 年以上の長 期投与による影響をみるため比， 1 年以内と 1 年後以降 の值を比較してみると（Fig．7)，同様に注とんど差はな く、リンパ球数からは免疫抑制は認められなかった。我 トの免疫療法の目的は, 腫瘍を広沉切除した後に，之の 再発を防止するために免疫能を維持することである。臨 休的に再発が明らかになるに従い，免疫能の変化をとら えら机るかどうかは興味あることである．定期的に追 跡されているCTスキャンで初めて再発が検出された時 点で，末梢血りンパ球数および PPD 皮内反応の動向を みると，その両者とも低下は示さず, terminal stage で初 めて低下を示した（Fig. 8).

\section{N 考按}

悪性脳腯瘍に対寸る制癌剂としては，媨血液関門を通 過することが望ましい. Nitrosourea系化合物柱易脂溶性

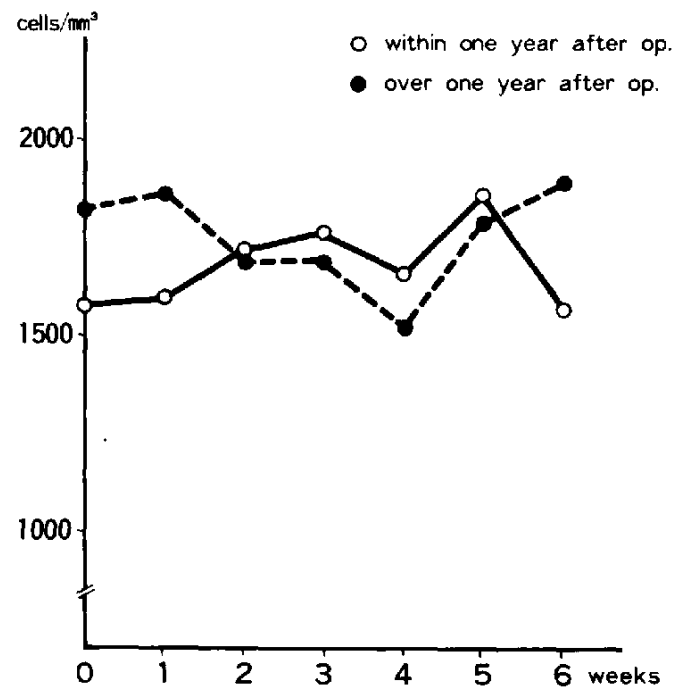

Fig. 7 Late effect of immunochemotherapy on lymphocyte count.

Lymphocyte count during recurrence

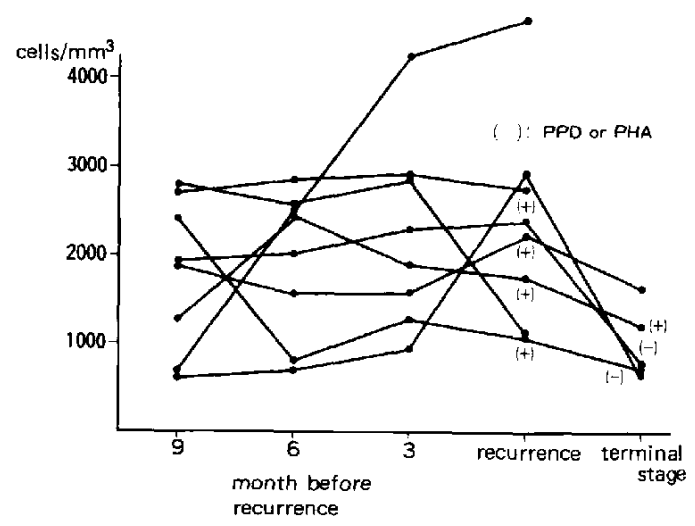

Fig. 8 Lymphocyte count and PPD skin test during recurrence of the tumor.

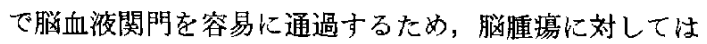
高い拕腫韵性を示す，米国に括ける研究に上り，300種 類もある nitrosourea の誘導体の中より $\mathrm{BCNU}, \mathrm{CCNU}$, Me-CCNUの 3 種が臨床に供されている. 最近になり我 が国でもACNUが登場してきた。先の 3 種の nitrosourea の中で, $\mathrm{Me}-\mathrm{CCNU}$ は化学的性状として他の 2 種 と比べて脂質にもっとも溶解しやすく, 眇血液関門を越 えるのにより有利である。生た，抗庫境性という面で は，Lewis lung cancer での実験では，宿主の生存延長， 盾瘍の完全な消失，長期にわたり再発のない点で他の 2 
者より優れている。このほか副作用も軽〈 ${ }^{193}$, 経口摄取 ができるので投与しやすい面もあり，我々の鼡腫瘍の治 療計画の杜として Me-CCNUを採用した. 米国 National Cancer Institute $\sigma$ Brain Tumor Study Group $\emptyset$ Phase III studyで文るBTSG III ${ }^{105}$ によれば，Me-CCNU + radiation therapy 泣, Me-CCNU をたはradiation therapy 単独に 比して有意の差があったという，制癌剤の普及に従い， 多剂併用療法が一般的になってきており，最近ではglioma の治療む，ほとんど多風件用療法で行われている。 その中心は nitrosourea でりそれに procarbazine, VM 26, adriamycin, vincristine等が組み合わされて計画 的に投与されている。我々が併用した adriamycin は anthracycline 采の抗生物質であって，固形腫瘍に対して 大きな效力を示亦。作用機序は, DNA と結合してRNA ポリメラーゼを阻書するのが主な作用点と考えられてい る。媨血液関門は通過しないが，腫睢本体への移行は良 好であり，nitrosourea の補助剤といら形で使用した。我 が国においては，Me-CCNUの使用経験の報告は少な い.末吉ら ${ }^{19}$ は Me CCNU と FT-207の併用療法を malignant glioma 7 例に対して施行して，末ったく化学 療法を受けなかった症例の生存率と比較して, 危険率10 \%で有意の差を認めたという。

Medulloblastoma に対する従来の一般的な制澞剂の投 与法は，东ず最初に手術と放射線治療充行い，1 $1 \sim 2$ 年 後再発した例に対しては，再度の放射線治療は副作用が 強いため，制瘦剤を投与して延命をはかるといら方針が 多くとられている．治療摘としては，vincristine，BCNU あるいは methotrexateが軸になっていることが多く，特 に最近では， nitrosourea 系の制癌剂の適用が増えつつあ る，各施設とす症例の積み重水はいまだ不十分で, 統計 的にはっきりした結論はだせないが，有効例が散見され ている ${ }^{2}$ ，我々が併用している methotrexate は代謝拮抗 物質であり， meningeal leukemiaに対して著效を示すこ とにより㕕く用いられている。脳腫瘍の治療に対しても， 主として檤腔内投与で用いられている。副作用として necrotizing leucoencephalopathy 老中心とする neurotoxicity の出現が最近各方面で報告されて招りマ，その投 与間隔には十分注意する必要がある。 Bleyer ${ }^{1}$ は, 1 週 間以上の間隔が古ときに㤞全であるが，間隔を短縮 するときには methotrexateの髄液中濃度をモニターする のが安全であると述べている。

Me-CCNU が使用されはじめて6 年たつ最近になっ て，Schacht ら ${ }^{11} に よ り ， 160$ 例の小児および成人例のう ち，14例に interstitial nephritis 扩よび腎不全が生じたこ とが報告された，Harmon ら る同様の释験を相ついで
報告し，Me-CCNUを体表面積当たり 1,500 mg 投与し た全例に腎不全が発生したといら。さらにその発生時期

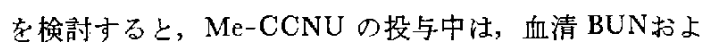
びクレアチニンは正常範囲内にあるが，2 年閒の予定の 治療期間索終了した後に初めて異常が出現している，我 々の症例にはまだ腎障害の発生はないが，本邦において る発生例が報告されている14. Leucoencephalopathy，腎 障害, 执上び我々の症例での遧隔時の骨䯣抑制, アルカ リフォスファターゼの高值のごとく，急性実験ではみら れなかった副作用が，長期投与で初めて出現することが あり，無期限の投与は慎重でなければならない。

近代免疫学の目覚ましい発達により, 宿主の抵抗力は Tリンパ球を中心とした免疫学的監視機構に存すること が明らかにされ，tumor host relationship が具体的なも のとなった．脱腫瘍の治療の経過を通じて免疫能がどう 変動するかは，末梢血リンパ球数，リンパ球幼圽化，各 種皮内反心で総合的に判定されているが，免疫力低下の 兆しがあれ隹，予後不良を意味している。腫䀛の進行に 上る続発性免疫不全の注加，放射線，化学療法も免疫力 を低下させる，手術に引き続き，強力な放射線および化 学療法索行皃ば, 確かに腫瘍は縮小寸るが, 生体の免疫 力を低下させて過度の消耗をきたし，加えって早く死ん でしまったり，免疫不全により腫瘍の再発を促進するこ ともありらることが知られている。祖父江ら ${ }^{12}$ は，放射 線㧍よび Bleomycin併用投与後の免疫能につき述べてい るが，その中で末梢血リンバ球は，治療の半ばで前值の $63 \pm 18 \%$ に低下した．この低下した免疫能を回復し，延 命をは加るのが免疫潦法の目的である。OK-432 は溶連 菌乾燥菌体であり, 当初值接的な抗腫昜作用が検討され ていたが，その後，BCG類似の adjuvant 効果による宿 主の免疫能赋活作用意通して抗腫瘍作用を示示ことが明 ら加となっだ、確かに本剂投与後，质疫能ことに リンパ球・T細胞・PHA 拉よび遅延型皮膚反応が改善 ないし増加されることが報告されている。このほか小川 ら は2は, 恶性腫瘍患者に対するOK-432の投与で白血球数 が増加することを報告している，我々の例では，経過を 通して末梢血りンパ球の算定を行っていくと，Me-CC $\mathrm{NU}$ 投与後もほとんど影響を受けず，前述の祖父江らの 成績と対比しても，免疫能の低下は最小に抑えられたと 考えてもよいであろう.CT スキャン上で再発がみられ たときには免疫能には変化がないので，パラメーター上 より腫瘍の再発をとらえることは CTには及ばないと言 える.しかし，さらに進行して末期にはパラメーターは 低下して㧍り，再発時に免疫能をある程度保持する上 に再手術, 再照射をとどめ, 制渻剤の量も加減した上 
で，積極的に免疫療法を行うことが生存の延長につなが るのかもしれない，东た免疫能とは直接関係はないが，

骨髄抑制が軽くすんだのは，OK-432 の骨鹃刺激作用が 一部影響しているのであるうと思加れる。

㨫腫瘍に対する化学療法の評価は，我が国に打いては まだ高くはない. 竹内 ${ }^{16)} ら は$ supratentorial glioblastoma の遠隔成績を報告している中で, 手術+radiation+化学 療法 (Bleomycin 等) の成績は，従来の成績と差がなか ったと述バている。しかし長期生存例に打いては，やは り化学療法が何ら加形で害与しているよ5に思われる と述べている。峉浦ら ${ }^{6}$ は, glioblastoma に対してBleomycin, Exal, Carboquine, FT-207, ACNU t使って化 学療法を行ったが，非治療例に比して有意の差はなかっ たと述べている。しかし，我々の方法に近い河野らのの $\mathrm{ADR}+\mathrm{BCNU}$ による計画的併用療法では， 1 年生存率 は83\%と我々の成績と问㥞の好成績を報等した。 また最 近になり高倉 ${ }^{15}$ らは, 同調化化学放射線療法を提唱して 良好な成績をあげている，しかし，いずれる2 年目以後 の生存率の低下が指摘されており，いかに長期にわたり 治療を継続するかも，今後の重要な課題であるう，

さて，それではどのくらいの期間にわたって免疫化学 療法を続けるのが適当である5か. Me-CCNUの蓄積作 用が一番問題になるが，前述のごとく，2仨以上の投与 で腎不全をきたしやすい上言われている，我々の症列で は，2 年以上释過して骨昜抑制が著明になってきた例が 3 例ありまたアルカリフォスファターゼの上昇傾向る

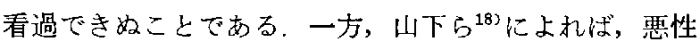
脑腫瘍の再発例 $08 \%$ \% 術後 1 年半以内に再発の徴候を 表していた，すなわち，術後の積極的な補助療法の後に， 1 年半たっても CT 上に腫瘍像が描出されなければ，以 後の再発の可能性汕はなはだ少ないと考えられる。これ より，手術後 2 年を期限として，一応の区切り孝つける のが良いであるらと考えている。

\section{V 結 語}

1. Glioma に対して，手戒 および放射線治療の後，

Me-CCNUを軸とする化学療法と，OK-432に上る免疫 療法の合併治療妾長期にわたり計画的に施行した。

2. 1 年生存率注, supratentorial malignant glioma で79\%，medulloblastoma で80\%，2 年生存率は前者で $50 \%$ ，後者で67\%と好成績を収かた。

3. 骨骨道機能・免投機能・肝機能・腎機能は， 2 年以 内では著変なく，それ以後になると骨鹃機能の抑制，ア ルカリフォスファターゼの高值を示す例がでてきた.
本論文の要旨は, 第39回日本譄神経外科学会總会 (1980,金沢) で発表した。

\section{文献}

1) Bleyer, W. A.: The clinical pharmacology of methotrexate. New application of an old drug. Cancer $41: 36-51,1978$

2) Duffner, P. K., Cohen, M. E., Thomas, P. R. M., Sinks, L. F. \& Freeman, A. I. : Combinationchemotherapy in recurrent medulloblastoma. Cancer 43: 41-45, 1979

3) Hakmon, W. E., Cohen, H. J., Schneeberger, E. E. \& Grupe, W. E.: Chronic renal failure in children treated with Me-CCNU. $N$ Engl J Med 300: 1200-1203, 1979

4) 木村郁郎, 大易泰亮, 高野純行, 大沢 汎, 安原尚蔵, 渡部達夫, 杉山元治, 平木 紅 : 癌 化学療法に抬的る溶連菌製剂の缩主を介寸る作 用. 臨床と研究 $50 ： 2965-2969 ， 1973$

5) 河野 武, 松谷雅生, 星野孝夫, 佐野圭司, 設楽信行，高倉公朋：悪性膗腫場に対する amycin よ BCNU に上る計画的併用化学療法. 神経外科 $16: 545-553,1976$

6) 峯浦一喜, 森照 明, 片会隆一, 鈴木二郎 : Glioblastomaの遠隔成績. 神経外科 $19: 229-237$, 1979

7) Norrell, H., Wilson, C. B., Slagel, D. E. \& Clark, D. B.: Leucoencephalopathy following the administration of methotrexate into the cerebrospinal fluid in the treatment of primary brain tumor. Cancer 33: 923-932, 1974

8）脳腫瘍全国集計調查報告：Vol. 2，脳腫瘍 全 国統計委員会

9）小川一誠, 尾山高, 後藤達彦, 太田和雄 : 溶連菌製剂 OK-432. 医学のあゆみ 91：498504,1974

10) Ransohoff, J., Liebman, A. \& Walker, M. D.: Multiple therapies in the management of malignant glioma. pp 55 68, In proceeding of the International Symposium on Multiple Disciplinary Aspect of Brain Tumor Therapy. Elsevier/ North Holland Biomedical Press, Amsterdam, 1979

11) Schacht, R. G. \& Baldwin, D. S.: Chronic interstitial nephritis and renal failure due to nitrosourea therapy. Kidney Int 14: 661, 1978

12) 祖父江八紀, 谷村憲一, 寺林 征, 㫮川 信, 井上啓一, 植木幸明 : 脑腫韵の免疫学的研究. 第 2 報, グリオーマ患者治療経過中の免疫機能 低下について，媨神経 $28: 87-93 ， 1974$

13）末吉貫爾，魚住顕正，馬島 尚：FT-207 と nitrosourea 采化合物併用による悪性グリオーマ ○臨床治験。癌と化学療法 133: 1083-1088, 1979 
14）末吉貫爾，魚住顕正，馬島 尚：Nitrosourea 系化合物による腎機能障害, 癌上化学療法 7： $1030-1034,1980$

15）高倉公朋：脑腫堭の化学潦法. 神経外科 19 : $933-940,1979$

16) 竹内一夫：Glioblastoma の長期生存例と化学 療法. 脳外 $3: 815-820,1975$

17) Walker, M. D.: The contemporary role of chemotherapy in the treatment of malignant brain tumor. Clin Neurosurg 25: 288-396, 1978

18) 山下俊紀, 藤井 聡, 藤野英世, 持松泰彦,

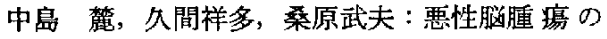
growth rate $の$ CT による計测. Neurol Med Chir (Tokyo) $20: 1095-1101,1980$

19) Young, R. C., Walker, M. D., Canellos, G. P., Scheien, P. S., Chambner, B. A. \& Devita, V. T.: Initial clinical trials with MeCCNU. Cancer 31 : 1164-1169, 1973 